\title{
Peningkatan Literasi Digital Melalui Pelatihan Komputer Dasar dan Media Sosial Pada Gapoktan Sedyo Makmur
}

\author{
Matahari Bhakti Nendya ${ }^{1}$, Gabriel Indra Widi Tamtama ${ }^{2}$, Antonius Rachmat Chrismanto ${ }^{3}$, \\ Argo Wibowo ${ }^{4}$, Rosa Delima ${ }^{5}$ \\ ${ }^{1,3,5}$ Program Studi Informatika, Fakultas Teknologi Informasi, Universitas Kristen Duta Wacana \\ Jl. Dr. Wahidin Sudirohusodo 5-25 Yogyakarta \\ 1didanendya@staff.ukdw.ac.id \\ $\underline{3 \text { anton@staff.ukdw.ac.id }}$ \\ ${ }^{5}$ rosa@staff.ukdw.ac.id \\ ${ }^{2,4}$ Program Studi Sistem Informasi, Fakultas Teknologi Informasi, Universitas Kristen Duta Wacana \\ Jl. Dr. Wahidin Sudirohusodo 5-25 Yogyakarta \\ ${ }^{2}$ gabriel@staff.ukdw.ac.id \\ ${ }^{4}$ argo@staff.ukdw.ac.id
}

\begin{abstract}
Abstrak - Pembangunan sumber daya manusia menjadi bagian yang penting dalam menunjang pembangunan bangsa dan negara. Salah satu sumber daya manusia yang perlu mendapat perhatian adalah kelompok tani. Gabungan kelompok tani (Gapoktan) merupakan wadah berkumpulnya para petani dan layak dalam mendapatkan prioritas dalam pembangunan bangsa. Gapoktan merupakan organisasi wadah pengembangan petani/kelompok tani yang tumbuh dan berkembang atas dasar kesadaran dan tanggung jawab sosial dari, oleh dan untuk masyarakat terutama di wilayah desa/kelurahan. Kemajuan bidang teknologi informasi dan komunikasi (TIK) yang semakin pesat membutuhkan sumber daya manusia yang mampu mengolah serta memanfaatkannya dengan baik. Untuk menjawab kebutan tersebut, tim pengabdian pada masyarakat FTI UKDW mengadakan pelatihan komputer dasar dan media sosial bagi Gapoktan Sedyo Makmur. Kegiatan yang dilakukan berupa pendampingan dan pelatihan akan kebutuhan dalam penggunaan teknologi informasi dan komunikasi. Kebutuhan penggunaan komputer dan sosial mediameliputi pembuatan surat menyurat, kebutuhan pembuatan laporan keuangan, pembuatan proposal dan model pemasaran produk hasil pertanian menjadi peran penting dalam model penggunaan komputer dan sosial media yang dibutuhkan oleh kelompok pertanian. Pelatihan komputer dasar dan media sosial ini, diharapkan dapat menjadi pilot project untuk penerapan digital marketing produk hasil pertanian. Dari hasil pelatihan didapatkan peningkatan kemampuan peserta sebesar $14,48 \%$ untuk pengunaan Microsoft word, $9,23 \%$ untuk penggunaan Microsoft Excel dan 2,87 \% untuk penggunaa Sosial Media
\end{abstract}

yang meliputi whatsapp business, instagram dan marketplace tokopedia.

Kata kunci-teknologi informasi dan komunikasi, computer dasar, social media, gabungan kelompok tani.

Abstract-Human resource development is an important part in supporting the development of the nation and state. One of the human resources that need attention is farmer groups. Gabungan Kelompok Tani (Gapoktan) are a forum for farmers

to gather and deserve priority in nation building. Gapoktan is an organization for the development of farmers that grows and develops on the basis of awareness and social responsibility from, by and for the community, especially in the village area. The advancement in the field of information and communication technology (ICT) which is increasingly rapidly requires human resources who are able to process and utilize it properly. To answer this problem, FTI UKDW community service team held computer and social media training for Sedyo Makmur Gapoktan. The activities carried out are in the form of mentoring and training on the needs in the use of information and communication technology. The need for the use of computers and social media, including the preparation of correspondence, making financial reports, making proposals and marketing models for agricultural products and social media needed by agricultural groups. This computer and social media training expected to be a pilot project for the application of digital marketing for agricultural products. From the results, the participants' abilities increased by $14.48 \%$ for the use of 
Microsoft word, 9.23\% for the use of Microsoft Excel and $2.87 \%$ for the use of social media which includes whatsapp business, instagram and marketplace tokopedia.

Keywords - information communication and technology, basic computing, social media, gabungan kelompok tani.

\section{Pendahuluan}

\section{A. Latar Belakang}

Pembangunan sumber daya manusia menjadi bagian yang penting dalam menunjang pembangunan bangsa dan negara [1]. Salah satu model pembangunan sumber daya manusaia adalaah penggunaan Teknologi Informasi dan Komunikasi (TIK). Perkembangan TIK secara masif mempengaruhi seluruh sektor kehidupan [2]. Termasuk dalam sektor pertanian.

Perkembangan dan pemanfaatan teknologi informasi dan komunikasi (TIK) berdampak pada cara hidup manusia mulai dari cara berkomunikasi, cara belajar, cara bekerja, cara berbisnis, dan lain-lain. TIK juga mengubah proses kerja dari statis menjadi digital, mobile, dan virtual [3].

Pemanfaatan TIK untuk pertanian apat dilakukan dengan beberapa model. Salah satu model penggunaan TIK dilakukan dengan memberikan pendampingan pengumpulan data petani memasukkan dalata dalam spreasdsheet dan memasukkan dalam sistem pemetaan lahan pertanian [4].

Model lain pemanfaatan TIK dengam melakukan publikasi potensi desa melalui pembuatan website profil desa. Penggunaan website profil desa juga membantu untuk menyebarluaskan kepada masyarakat di luar desa tersebut [5].

Pemanfaatan TIK dilakukan sebagai upaya peningkatan kemampuan dan ketrampilan PPL dan Ketua Kelompok Tani secara intensif dalam aspek penguasaan teknologi informasi dan multimedia, pengetahuan berbagai jenis aplikasi penyuluhan, dan upaya peningkatan ketrampilan PPL dan Ketua Kelompok Tani dalam mengakses aplikasi media penyuluhan yang ada secara baik dan mudah [6].

Untuk meningkatkan penggunaan TIK oleh petani perlu adanya tahapan adopsi TIK. Model ini dapat diterapkan denan menggunakan lima langkah strategis, yaitu adopsi TIK secara bertahap, penyederhanaan dan pengemasan kembali informasi yang diperoleh melalui aplikasi TIK, penyediakan akses informasi, peningkatkan partisipasi dan kesadaran petani akan manfaat TIK, dan kemitraan antara petani dan penyedia layanan informasi [7].

Model Pemanfaatan TIK yang dirasa sangat perlu adalah untuk meberikan akomodasi dan akses pada kelompok tani. Kelembagaan kelompok tani dan Gapoktan difasilitasi dan diberdayakan oleh pemerintah agar tumbuh dan berkembang menjadi organisasi yang kuat dan mandiri sehingga mampu mencapai tujuan yang diharapkan para anggotanya. Pemerintah sudah banyak memberikan bantuan, di antaranya bimbingan dan penyuluhan, bantuan permodalan baik dalam bentuk pendanaan maupun Alsintan, serta subsidi pupuk dan benih [8].

Gapoktan merupakan organisasi wadah pengembangan petani/kelompok tani yang tumbuh dan berkembang atas dasar kesadaran dan tanggung jawab sosial dari, oleh dan untuk masyarakat terutama di wilayah desa/kelurahan [9].

Kemajuan bidang teknologi informasi dan komunikasi (TIK) kini semakin pesat, perkembangan tersebut membutuhkan sumber daya manusia yang mampu mengolah serta memanfaatkannya dengan baik. Seiring perkembangan teknologi tersebut, kebutuhan untuk mengerjakan sesuatu kini ditekankan untuk memakai teknologi karena lebih cepat dan efisien [10].

Keterampilan dalam menggunakan komputer dan sosial media saat ini sudah menjadi tuntutan guna menunjang kegiatan dalam berorganisasi dan berniaga bagi kelompok tani. Kegiatan administrasi, kebutuhan pembuatan surat menyurat, kebutuhan pembuatan laporan keuangan, pembuatan proposal dan model pemasaran produk hasil pertanian menjadi peran penting dalam model penggunaan komputer dan sosial media yang dibutuhkan oleh kelompok pertanian.

Berdasarkan kebutuhan tersebut Gabungan Kelompok Tani (Gapoktan) "Sedyo Makmur" yang beralamatkan di Desa Gilangharjo, Kecamatan Pandak, Kabupaten Bantul meminta dukungan dari tim Fakultas Teknologi Informasi (FTI) Universitas Kristen Duta Wacana (UKDW) untuk memberikan pendampingan dan pelatihan komputer dasar dan sosial media. Oleh karena itu dalam usulan kegiatan Pengabdian Kepada Masyarakat ini akan dijalankan program pelatihan komputer dasar yang meliputi penggunaan Microsoft Word dan Microsoft Excel untuk keperluan pembuatan surat menyurat, pembuatan proposal dan pembuatan laporan keuangan serta penggunaan sosial media sebagai media promosi penjualan hasil pertanian.

Melalui program ini, pihak Gapoktan Sedyo Makmur berharap tim FTI UKDW dapat membantu anggotanya dalam peningkatan kemampuan penggunaan komputer dasar microsoft Word dan Microsoft Excel serta penggunaan sosial media untuk penjualan hasil pertanian. Disamping itu, pihak Gapoktan juga berharap supaya anggota mereka dapat mandiri dalam hal penggunaan teknologi informasi dan sosial media yang menunjang dalam produksi dan promosi hasil produk pertanian.

\section{B. Rumusan Masalah}

Permasalahan umum yang dihadapi oleh Gapoktan Sedyo Makmur adalah belum mampu menggunakan teknologi informasi dalam hal ini komputer dasar dan sosial media untuk menunjang kebutuhan administrasi dan promosi hasil produk pertanian. 


\section{Tujuan dan Manfaat}

Tujuan dari diadakannya kegiatan pengabdian ini antara lain adalah:

1. Meningkatkan pengetahuan masyarakat, terutama kelompok tani tentang teknologi informasi dalam penggunaannya untuk keperluan pembuatan surat menyurat, pembuatan proposal kegiatan dan pembuatan laporan keuangan serta penggunaan media sosial dalam untuk menunjang kegiatan perta.

2. Mengenalkan penggunaan media sosial bagi masyarakat terutama kelompok tani untuk membantu dalam pemasaran produk hasil pertanian.

\section{METODE PELAKSANAAN}

Tujuan utama pada pengabdian ini adalah Pelatihan dan Pemebajaran. Metode pembelajaran adalah cara atau tahapan yang digunakan dalam interaksi antara peserta didik dan pendidik untuk mencapai tujuan pembelajaran yang telah ditetapkan sesuai dengan materi dan mekanisme metode pembelajaran [11].

Pelatihan meliputi pemberian petunjuk secara tepat kepada pengguna mengenai bagaimana mereka akan menggunakan perangkat lunak. Pelatihan harus mencakup sesi praktik langsung

Proses pengabdian dilakukan dalam beberapa tahap. Tahap-tahap yang dilakukan dalam kegiatan pengabdian ini adalah sebagai berikut:

\section{A. Tahap 1: Pembuatan materi Pelatihan Komputer Dasar dan Media Sosial}

Tahap ini merupakan pengolahan data-data yang didapatkan berdasarkan tatap muka dan koordinasi pada tahap 1. Penulis merancang bagaimana pelatihan akan dilakukan dan materi yang akan disampaikan. Keluaran pada tahap ini adalah materi ajar, cara pelatihan, dan waktu pelatihan. Pada awalnya disiapkan pelatihan tatap muka seperti biasa, dengan menyiapkan modul pelatihan yang ringkas namun terperinci.

\section{B. Tahap 2: Proses Pelatihan Komputer Dasar dan Media Sosial}

Pada tahap ini penulis melakukan pelatihan komputer dasar dan sosial media kepada Gapoktan dibawah naungan BPP Pandak. Pelatihan ini bertujuan agar anggota gapoktan dapat menggunakan aplikasi komputer dasar dan soial media dengan fasih. Pelatihan diisi dengan mengajarkan cara penggunaan Microsoft word, Microsoft excel, sosial media berupa whatsapp business dan Instagram serta aplikasi marketplace Tokopedia. Tiap peserta akan mendapatkan materi pelatihan. Pelatihan dilaksanakan pada hari Rabu-Kamis, 9-10 September 2020 bertempat di BPP Pandak, Kabupten Bantul.

Materi pelatihan hari Pertama meliputi komputer dasar dan penggunaan apilkasi perkantoran Mircosoft Office. Untuk aplikasi Microsoft Office dikhususkan pada aplikasi Microsoft Word dan Microsoft Excel. Materi pelatihan Microsoft word meliputi pembuatan surat menyurat dan pembuatan laporan, sementara untuk materi pelatihan Microsoft Excel fokus kepada pembuatan laporan keuangan sedaerhana.

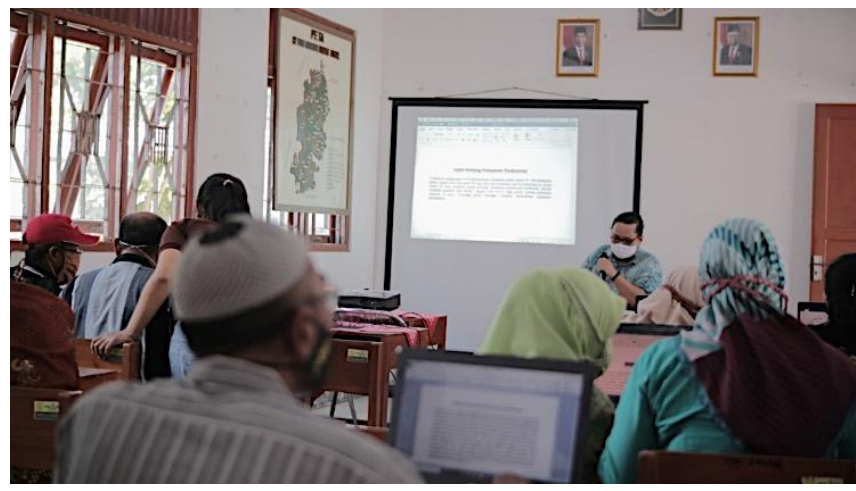

Gambar 1 Suasana Pelatihan Komputer Dasar di BPP Pandak

Pelatihan hari kedua dilaksanakan pada kamis 10 September 2020. Materi yang diberikan pada pelatihan jari kedua meliputi penggunaan whatsapp business, Instagram dan makterplace sosial media. Pada pelatihan sosial media ini difokuskan bagaimana melakukan promosi produk hasil pertanian dari Gapoktan.

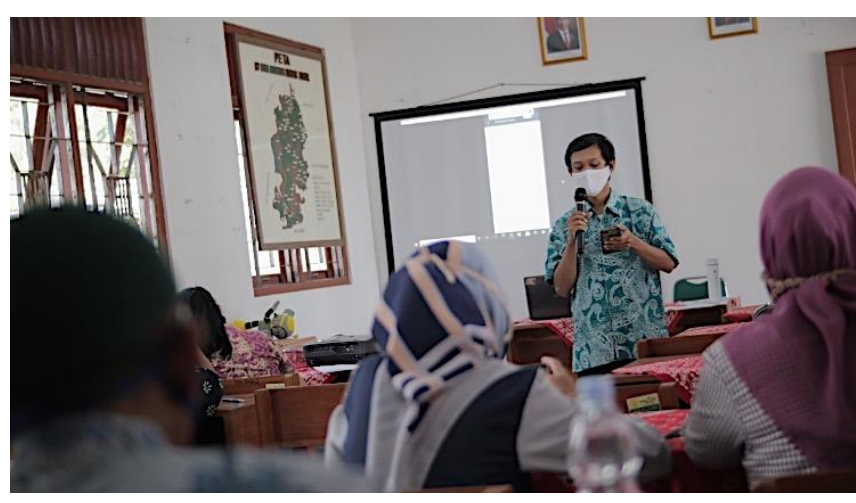

Gambar 2 Suasana Pelatihan Sosial Media Di BPP Pandak

\section{Tahap 3: Evaluasi Pelatihan}

Setelah melalui proses pelatihan, aktivitas selanjutnya adalah evaluasi pelatihan untuk mengukur keberhasilan pelatihan bagi anggota Gapoktan. Evaluasi dilakukan dengan memberikan latihan kasus membuat surat, pembuatan proposal, laporan keuangan dan penggunaan sosial media dan aplikasi marketplace. 


\section{Tahap 4: Analisis Hasil Pelatihan}

Pada tahap ini penulis melakukan analisis dari keberhasilan program Pengabdian kepada Masyarakat. Hasil analisis dilakukan untuk menjadi dasar dan merusmuskan tindak lanjut program pendampingan dan pelatihan komputer dasar dan sosial media bagi anggota Gapoktan.

\section{DISKUSI}

Materi yang disampaikan pada hari pertama adalah pengoperasian komputer dasar, yang meliputi aplikasi pengolah kata Microsoft Word untuk membantu pembuatan administrasi kebutuhan Gapoktan yang meliputi pembuatan surat menyurat dan laporan. Materi berikutnya diberikan pelatihan terkait dengan penggunaan dan pengoperasian perangkat lunak spreadsheet untuk membantu administrasi usaha, yang dalam hal ini digunakan contoh laporan keuangan sederhana.

Di dalam kegiatan pelatihan ini, diberikan pretest dan posttest untuk mengukur seberapa kemampuan peserta pelatihan sebelum dan sesudah pelatihan. Selain itu, di dalam kegiatan pelatihan ini akan diberikan juga latihan yang sesuai dengan materi pelatihan, yaitu Microsoft Office yang meliputi Word dan Excel.

TABEL I

HASIl PRESTES DAN POSTEST PELATIHAN KOMPUTER DASAR

\begin{tabular}{|l|l|r|r|r|r|}
\hline \multirow{2}{*}{ No } & \multirow{2}{*}{ Nama } & \multicolumn{2}{|c|}{ Microsoft Word } & \multicolumn{2}{c|}{ Microsoft Excel } \\
\cline { 3 - 6 } & & Pretest & Posttest & Pretest & Posttest \\
\hline 1. & Dalmini & 9 & 9 & 7 & 10 \\
\hline 2. & Jumarni & 9 & 11 & 3 & 6 \\
\hline 3. & Mardiyah & 9 & 11 & 4 & 3 \\
\hline 4. & Mulyono & 4 & 5 & 4 & 6 \\
\hline 5. & Subandi & 0 & 6 & 0 & 3 \\
\hline 6. & Supriadi & 11 & 12 & 11 & 10 \\
\hline 7. & Puji Lestari & 12 & 9 & 8 & 6 \\
\hline 8. & Yuli Yanta & 9 & 10 & 7 & 8 \\
\hline 9. & Sriyono & 7 & 7 & 3 & 7 \\
\hline 10. & Bani Wijaya & 10 & 10 & 12 & 11 \\
\hline 11. & Siswantya & 10 & 8 & 5 & 8 \\
\hline 12. & Latifah & & & & - \\
\hline 13. & Nurhidayati & 10 & - & 14 & - \\
\hline & Tri Tusilawati & 9 & - & 14 & $\mathbf{7 , 8 0}$ \\
\hline
\end{tabular}

Tabel 1 merupakan hasil pretest dan postest pelatihan komputer dasar. Dari data yang disajikan secara rata-rata kemampuan peserta mengalai kenaikan setalah melalui pelatihan komputer dasar. Untuk materi microsoft word, mengalami kenaikan nilai rata-rata 1,42 poin atau sekitar $14,48 \%$. Dari sebelum pelatihan mendapatkan nilai ratarata 8.38 dan setelah pelatihan mendapatkan nilai rata-rata 9.80 .
Kenaikan nilai rata-rata juga terjadi pada pelatihan komputer dasar dengan materi Microsoft Excel. Sebelum pelatihan mendapatkan nilai rata-rata 7.08 dan setelah pelatihan mendapatkan nilai rata-rata 7,80. Bisa dikatakan setelah pelatihan mengalami kenaikan nilai rata-rata sebesar 0.72 poin atau sekitar $9,23 \%$.

Pada pelatihan hari pertama, ada 2 orang peserta yang tidak mengikuti postest dikarenakan ada keperluan lain setelah pelatihan. Untuk itu data dari 2 orang peserta tersebut hanya ditampilkan dalam tabel tetapi tidak ikut dihitung untuk mengetahui kenaikan nilai rata-rata kemampuan peserta pelatihan.

Pelatihan hari kedua dibagi menjadi 2 sesi. Pada sesi pertama, materi yang disampaikan adalah penggunaan whatsapp businessyang meliputi cara pembuatan, penggunaan dan penggunaan fitur autoreply. Sedangkan pada sesi kedua diberikan materi mengenai penggunaan sosial media seperti instagram dan pengenalan marketplace seperti tokopedia untuk pengembangan bisnis hasil pertanian.

Di dalam kegiatan pelatihan ini, diberikan pretest dan posttest untuk mengukur seberapa kemampuan peserta pelatihan sebelum dan sesudah pelatihan. Selain itu, di dalam kegiatan pelatihan ini akan diberikan juga latihan yang sesuai dengan materi pelatihan, yaitu penggunaan sosial media berupa whatsapp bussines, instagram dan marketplace tokopedia. Berikut ini hasil dari prestest dan postest pelatihan sosial media.

TABEL 2

Hasil Prestes dan Postest Pelatihan Media Sosial

\begin{tabular}{|r|l|r|r|}
\hline \multirow{2}{*}{ No } & \multirow{2}{*}{ Nama } & \multicolumn{2}{|c|}{ Sosial Media } \\
\cline { 3 - 4 } & & 6 & Pretest \\
\hline 1. & Dalmini & 8 & 6 \\
\hline 2. & Jumarni & 6 & 5 \\
\hline 3. & Mardiyah & 4 & 0 \\
\hline 4. & Mulyono & 4 & 6 \\
\hline 5. & Subandi & 7 & 8 \\
\hline 6. & Supriadi & 8 & 7 \\
\hline 7. & Puji Lestari & 6 & 7 \\
\hline 8. & Yuli Yanta & 5 & 9 \\
\hline 9. & Sriyono & 7 & 9 \\
\hline 10. & Bani Wijaya & 6 & 7 \\
\hline 11. & Siswantya & $\mathbf{6 , 0 9}$ & $\mathbf{6 , 2 7}$ \\
\hline & Rata-Rata & & \\
\hline
\end{tabular}

Tabel 2 merupakan hasil pretest dan postest pelatihan sosial media. Dari data yang disajikan secara rata-rata kemampuan peserta mengalai kenaikan setalah melalui pelatihan sosial media. Sebelum pelatihan, peseta mendapatkan nilai rata-rata 6,09 dan setelah pelatihan mendapatkan nilai rata-rata 6,27 . Bisa dikatakan setelah pelatihan mengalami kenaikan nilai rata-rata sebesar 0,18 atau sekitar $2,87 \%$ 


\section{KESIMPULAN}

Kegiatan pelatihan dengan mitra Gapoktan Sedyo makmur memberikan dampak yang positif anggota dan Gapoktan lain yang berada dibawah naungan BPP Pandak. Dengan adanya pelatihan ini dapat meningkatkan kemampuan peserta dalam memahami komputer dasar, seperti pengolah kata, pengolah spreadsheet dan sosial media seperti penggunaan whastapp business, Instagram dan marketplace tokopedia. Hal ini terlihat dari meningkatnya kemampuan peserta yang dapat di indikasikan dari meningkatnya hasil posttest dibandingkan dengan pretest. Dari hasil prestest dan posttes yang dilakukan terjadi peningakatan kemampuan sebesar 14,48 \% untuk penggunaan Microsoft Word 9, $23 \%$ untuk penggunaan Microsoft Excel dan 2,87 \% untuk penggunaan media sosial Whastapp Business, Instagram dan marketplace Tokopedia.

\section{UCAPAN TERIMA KASIH}

Ucapan terimakasih diberikan kepada Gapoktan Sedyo Makmur dan Badan Penyuluh Pertaninan Pandak Kabupaten Bantul yang telah memberikan kepercayaan kepada Tim Pengabdian. Juga diucapkan terima kasih kepada FTI UKDW yang telah membantu pendanaan sehingga pelatihan ini dapat berjalan dengan lancar di tengah pandemi Covid-19 yang masih berlangsung.

\section{DAFTAR PUSTAKA}

[1] O. Wakerkwa, "Peranan Sumber Daya Manusia Dalam Meningkatkan Pembangunan Masyarakat Di Desa Umbanume Kecamatan Pirime Kabupaten Lanny Jaya,' J. Holistik, vol. IX, no. 3, pp. 1-22, 2016.

[2] Jamun and Y. Maryono, "Pelatihan Keterampilan Dasar Komputer Dan Teknologi Informasi," RANDANG TANA J. Pengabdi. Masy., vol. 2, no. 2, pp. 89-178, 2019.

[3] J. Budiman; Yusrizal; Damanik, “Akses Dan
Penggunaan Teknologi Informasi Dan Komunikasi Pada Rumah Tangga Dan Individu," J. Penelit. Komun. dan Pembang., vol. 15, no. 1, pp. 1-16, 2014, doi: 10.31346/jpkp.v15i1.1323.

[4] R. Delima, J. Purwadi, H. B. Santoso, and A. Wibowo, "Penguatan Kapasitas Kelompok Tani Harjo dan Tani Rahayu dalam Komputerisasi Pendataan Petani," J. Pengabdi. Kpd. Masy., vol. 2, no. 3, pp. 1-6, 2019.

[5] H. B. Santoso, R. Delima, and A. Wibowo, "Pelatihan Pengembangan Web Profil Desa bagi Aparatur Pemerintah Desa," E-Dimas J. Pengabdi. Kpd. Masy., vol. 10 , no. 1 , p. 41,2019 , doi: $10.26877 / \mathrm{e}-$ dimas.v10i1.2592.

[6] R. Rendra, J. Jamaluddin, and F. Sativa, "Pelatihan PenggunaanMedia Aplikasi Penyuluhan Berbasis Android bagi PPL dan Ketua Kelompok Tani di Balai Penyuluh Pertanian (BPP) Kec. Hamparan Rawang Kota Sungai Penuh,” J. Karya Abdi Masy., vol. 3, no. 2, pp. 278-285, 2019, doi: 10.22437/jkam.v3i2.8502.

[7] K. Suarsana and N. K. Karyati, "Adopsi Teknologi Informasi Komputer Dan Implikasinya Bagi Pertanian Di Bali," J. Manaj. AGRIBISNIS (Journal Agribus. Manag., vol. 8, no. 1, p. 61, 2020, doi: 10.24843/jma.2020.v08.i01.p06.

[8] S. Hanggana, "Analisis Kelemahan Regulasi Poktan, Gapoktan, UPJA dan LKM-A Dalam Peningkatan Pendapatan Petani," Anal. Kebijak. Pertan., vol. 15, no. 2, pp. 137-149, doi: http://dx.doi.org/10.21082/akp.v15n2.2017.137-149.

[9] M. V. Koampa, O. L. S. Benu, M. M. Sendow, and V. R. B. Moniaga, "Partisipasi Kelompok Tani Dalam Kegiatan Penyuluhan Pertanian Di Desa Kanonang Lima, Kecamatan Kawangkoan Barat, Minahasa," AgriSosioekonomi, vol. 11, no. 3A, p. 19, 2015, doi: 10.35791/agrsosek.11.3a.2015.10294.

[10] H. Indrayani, "Penerapan Teknologi Informasi Dalam Peningkatan Efektivitas, Efisiensi Dan Produktivitas Perusahaan," J. EL-RIYASAH, vol. 3, no. 1, p. 48, 2012, doi: 10.24014/jel.v3i1.664.

[11] M. Afandi, E. Chamalah, and O. P. Wardani, Model Dan Metode Pembelajaran Di Sekolah, vol. 392, no. 2. Semarang: UNISSULA Press, 2013. 